cyst with very thick walls. The cavity was of about the size of a pea and contained clear watery-looking fluid in which floated a thin, very delicate membrane. Under the microscope this membrane showed no traces of organised tissue or epithelium, but appeared as a transparent membrane covered with calcareous particles. Attached to the end was a small vesicle apparently of the same structure through the wall of which could be seen a circle of hooklets. By careful manipulation I succeeded in making the head of the echinococcus to protrude. It had four large suckers and a corona of twenty hooklets placed in two more or less distinct rows.

Hydatid cysts do not appear to have been frequently met with in this position. Davain in his "Traité des Fin tozoaires" (second edition) mentions two cases of hydatids in the axillary region and one in the pectoralis major muscle. In The Lancet of August 17th, 1895, Dr. W. J. Collins reported a case of hydatid cyst of the right axilla which was operated on by him and in which " the diagnosis remained uncertain until the operation, although fatty tumour and chronic abscess had been suggested." With regard to the origin of the hydatid cyst in my case, the mother of the child informed me that the water-supply of their farm was derived from a well and that she had often noticed it to be full of insects and living organisms. She also stated that the child had from an early age shown a great liking for raw meat and uncooked vegetables. Personal hygiene did not appear to be one of the mother's strong points.

Brussels.

\section{VIABILITY IN CHILDREN.}

By C. H. L. Johnston, M.D., L.R.O.S. Edin.

THE following case is worth recording. A married woman, the mother of two children, who had been a patient under my care for about ten years, was visited by me and delivered of a living male infant at 4 A.M. on Dec. 2nd, 1898. She stated that she had last menstruated on June 6th, 1898, that she felt the movements of the child about the middle of October, and considered herself six months pregnant. The infant was very small; his skin was of an intense red colour, much wrinkled, and covered with a down, and there was an absence of sebaceous matter. Not deeming it advisable to use water I directed the nurse to wipe the child and after enveloping him in flannel placed him in bed beside the mother. At first some diluted sweetened milk was given which the stomach rejected. The day after his birth he weighed 1lb. 13oz, avoirdupois and his length was $12 \frac{1}{4} \mathrm{in}$. More diluted milk was given which was retained and also a few drops of port wine. Although he was kept in a room at a uniform temperature, was covered with flannel, and took a small quantity of nourishment, he did not possess sufficient vital energy to keep the body warm, and he died on the evening of Dec. 4th, having survived his birth two and a half days. Assuming conception to have taken place after the last menstruation the duration of gestation would be 178 days or under six months.

St. John, New Brunswick.

THE TOPICAL USE OF QUININE IN LEUCORRHAEA.

BY W. WRIGHT HaRDWICKE, M.D. ST. AND., M.R.C.P., L.R.C.S. EDIN.

QUININE topically applied to the mucous surfaces of the cervix uteri and vagina was suggested by the good effects accidentally manifested by this drug when used in the form of pessaries though for quite a different purpose. A patient, the mother of six children, who had been a sufferer from the above complaint for some years, having used the various remedies usually prescribed in such cases but with only temporary benefit, her trouble sooner or later recurring, adopted the use, from prudential motives, of what I found to be quinine pessaries. I learned from her that since using them not only bad her leucorrhoea disappeared bat her general health had improved also. Though she had been in the habit of using from two to four of these pessaries a week for a period of over two years she had never suffered any ill-effects such as quinism. I have since used quinine topically in several cases of simple leucorrhoea and in every case with great success--in fact, I do not know of a single instance in which it has failed or in which quinism has been. produced. It may be used in the form of douche or pessary. I adopt the latter form as being obviously the better one, the drug having a better chance of closer and more continuous. contact with the congested membrane. I prescribe three grains of the hydrobromate in a half-drachm pessary in combination with oleum theobromatis, but the pessus quininæ. of the "Extra Pharmacopoia" containing the hydrochloride answers just as well. One insertion a day is generally. sufficient, a good result being very soon manifest.

It is a matter of astonishment that quinine in the form of pessary has never been used before in the treatment of leucorrhoea and ulceration, for its valuable properties-tonic, astringent, and antipyretic-suggest it as a useful remedy in such cases, but I can find no record of such in any of the well-known works on the subject.

East Molesey.

\section{d aftirror}

or

\section{HOSPITAL PRACTICE, BRITISH AND FOREIGN.}

Nulla autem est alla pro certo noscendi via, nfsi quamplurimas e morborum et dissectionum historias, tum aliorum tum propriss. collectas habere, et inter se comparare.-MoReAGNI De Sed, et Caus. Morb., lib. iv. Procmium.

\section{ST. BARTHOLOMEW'S HOSPITAL.}

\section{A CASE OF RUPTURE OF THE SMALL INTESTINE WITHOUT} EXTERNAL WOUND ; ABDOMINAL SECTION ; SUTURE; RECOVERY.

(Under the care of Mr. W. J. WALsham.)

IN the Mirror of Hospital Practice we published recently ${ }^{4}$ an account of an interesting case at St. Thomas's Hospital, under the care of Mr. W. H. Battle, in which the intestine ruptured without external wound was suturec. and the patient survived the operation nearly a month, dying finally from an abscess behind the liver. In the following case also the intestine was torn without any wound of the abdominal wall and the very successful result may be in great part attributed to the short interval: (less than two and a half hours) which elapsed between the accident and the operation. In some introductory remarks to the case already mentioned we pointed out that disappear ance of liver dulness was by no means invariably found in rupture of the stomach or intestine and Mr. Walsham's. case illustrates this point very clearly. With regard to the use of morphia in abdominal operations we think it im possible to lay down hard and fast rules. There is at present a disinclination to employ it, but a reaction in the opposite direction is by no means unlikely. If only sufficient morphia is administered to allay the irritation and to calm the patient and not enough to produce troublesome constipation or to hide dangerous complications then in our opinion the morphia will do nothing but good. For the notes of the case we are indebted to Dr. Gilbert Smith, house surgeon, and Mr. Hulton, dresser.

A boy, thirteen years of age, was admitted into the surgery ward of St. Bartholomew's Hospital under the care of Mr. Walsham on June 16th, 1898, at 8.40 P.M. He had just been knocked down by an empty four-wheeled postoffice van, a wheel of which had apparently passed across the upper part of the abdomen. On admission the patient was pale and collapsed ; the pulse was 78 , small, and feeble, and the temperature was normal. The abdomen was slightly retracted but moved feebly on respiration and was not hard or very tender on palpation. There was a mark across the abdomen just above the umbilicus such as might have been produced by the passage of a wheel. The liver dulness was not lost and it was thought that there was some slight dulness in the left flank. The lad complained of severe pain. in the back and there was some bruising over the spine at $z$ 